\title{
Book Review: Digital, Political, Radical
}

Fenton, Natalie. (2016) Digital, Political, Radical Cambridge, UK: Polity Press. 232 pp., ISBN: 978-0-7456-5086-9

CHRYSI DAGOULA, University of Groningen

\section{KEYWORDS}

Digital, political, radical, technology, democracy

Digital, Political, Radical is a challenging book about politics and democracy. Natalie Fenton, encourages the readers to take a step back from their preconceptions certainties, and to "open their arms and their minds a little wider" (Fenton 2016, 149) in order to understand, to embrace, and, ultimately, to be able to analyse actual politics. Setting the expectations right from the start, the book aims to challenge current debates, to offer a pragmatic perception of politics, and to frame these discussions within a social, political, cultural and economic context.

The starting point for Fenton's insightful analysis is the collapse of global capitalism in 2007 and the unsettling situation this created for democracy with the increased power of corporations and the decreased influence of the public on policies. However, she also discusses the glimpse of hope that has been expressed through various forms of 'public manifestations of dissent' (Fenton 2016, 9). Fenton sets herself a difficult but important task: she asks us to rethink the seemingly basic, but highly significant and fundamental questions of "what is politics?" and "where is democracy?", aiming to respond to the equally significant questions of "how do we do democracy better?" and consequently to "what are the conditions required to live together well?" (Fenton 2016, 9).

As revealed by the title, the book covers three broad themes. Fenton develops her discussions around the digital, the political, and the radical, bringing in two other, complimentary and vital aspects: the critical and the contextual.

Starting with the digital, the book engages with academic discussions on the transformative powers of new technologies, highlighting, the tendency to overly focus on their potential to rejuvenate politics, rather than lifting the social and political critique that according to Fenton should accompany them. In other words, Fenton refers to the overemphasis on the technological capabilities of the internet - that manifest themselves through the characteristics of speed and space, horizontality and diversity, as well as connectivity and participation rather than on the discourse that surrounds these technological functions. As Fenton notes, technologies are never neutral: they are "enmeshed with the systems of power within which they exist" (Fenton 2016, 135). Likewise, the networks that they facilitate are not "inherently liberatory", they not constitute a direct path to democracy. 
Power is the key reference point in Fenton's argumentation - to rethink politics starts with power. Fenton builds her approach to the political by discussing politics both as the ordinary and the extraordinary. The first points to the "politics of being" and the passion that drives politics - in this sense, politics are affected by a synthesis of emotions and a collection of affective responses. The latter, on the other hand, focuses on the notion of "being political" and on how we (should) seek to alter the terrain of power. The ordinary and the extraordinary are interlinked: politics has to do with the individuals' outlook on the world and the way they approach others, but at the same time with our collective standing, as political subjects, who are "being political" when we address questions related to the (re)distribution of resources and translate them into organizational and institutional practices. Fenton's reasoning is guided by the question "what are the conditions required to live together well?". The answer to this question is to be found by prompting a new set of questions that respond to who gets what, why, how and where. In other words, power must be approached from the perspective of powerlessness/the lack of power and arrangements of counter-power.

Widening the frame of the discussion, these questions highlight how politics can (and should, according to Fenton's analysis) be conceived of as radical. Whereas this term has been used widely and attached to a diversity of meanings, Fenton here refers to radical progressive politics construed primarily as "of the left" and uses it in relation to the Latin origins of the term "roots", suggesting that radical politics is of the "grassroots": "it emerges from below and nourishes what happens above" (Fenton 2016, 15). Radical politics therefore is politics of the people. This definitional approach itself encourages a mental connection with the definition of democracy - etymologically the term means "rule by the people" - and Fenton follows this path. Radical politics here is a constant negotiation with democracy, it is "a constant dynamic process of inclusiveness, engagement, debate and struggle" (Fenton 2016, 17) to realize alternatives. In that sense, radical politics is the politics of emancipation, and it is concerned with political efficacy. In other words, radical politics is about political pragmatism, or, about putting "what is at stake in the actual politics on offer" (p.16) at the heart of the discussions (and the research).

Fenton underlines that it is of outmost importance to understand the context: "how the 'political' gains meaning is deeply embedded in social context" (Fenton 2016, 13). In other words, the discussion about power relies on our understanding of the roles of the market and of the state, which have a direct effect on every aspect of the digital, the radical and the political. Fenton outlines the relationship between the political and the financial situation, by referring to the economic dislocation and the current imposed constraints as challenges to democracy. She highlights that democracy should be protected from the "footloose logic of the market", or at a minimum, the need to democratically harness "the dynamics of the international capitalist market to the needs and interests of the citizens in any given political community" (Fenton 2016, 22). Fenton's use of empirical examples to explain her perceptions of the politics of being and being political enables the reader to travel down her conceptual pathways. Drawing on the recent cases of the left-wing political parties Syriza in Greece and Podemos in Spain, Fenton provides a clear and well-thought through proposition 
for how we can confront transformations in politics in a digital age and for how to move forward: by repoliticizing the economy and by resocializing the political.

The book is about the digital, the political and the radical, but at the same time it is about the critical. The author approaches the debates from the viewpoint of critical theory. She agrees with Horkheimer's reasoning that critical theory differentiates from traditional theory due to its specific practical purpose, which is to seek human emancipation, liberating human beings from the situations that enslave them (Fenton 2016, 11). This reasoning aligns with the argumentation Fenton develops throughout the book and with her aim: to move beyond description; to insist on dialectics which insist on the possibility of change; to be explanatory, practical and normative; and finally to be reconstructive and deconstructive. At the same time, this approach could be regarded as a "deliberative attempt to re-focus our critical lenses on a politics of transformation in the field of media and communication" at a time when we are at a loss to explain the most basic questions: "who is saying what to whom and why it matters" (Fenton 2016, 11). Radical politics relies on the production of knowledge and meaning making, areas where the media has a prominent role.

Fenton's thought-provoking book poses questions for further academic discussion, by pointing to issues that need to be discussed and re-discussed and to ways in which critical research could be reinvigorated. At the same time the book poses a challenge to media research: to bring politics back in to the picture. Fenton builds a dialectic approach in her book, which manages simultaneously to be explanatory, practical and normative; it explains how we experience politics in a digital age and how this may influence our ability to be political (Fenton 2016, 25); it engages with contemporary examples (such as the Occupy movement) which offer a practical overview; and it dives straight into conceptual inquiries and theoretical discussions related to the digital, the political and the radical.

\section{References}

Fenton, N. (2016) Digital, Political, Radical Cambridge, UK: Polity Press.

\section{Biography}

Dr Chrysi Dagoula is an assistant professor at the Centre for Media and Journalism Studies at the University of Groningen. She earned her $\mathrm{PhD}$, entitled 'The Ongoing Structural Transformations of the Digital Public Sphere(s): The Role of Journalism', in 2017 from the University of Sheffield. Her research reflects her broader academic interests on the developments in digital political communication and in digital journalism.

Email: c.dagoula@rug.nl 